ORIGINAL ARTICLE

PRACA ORYGINALNA

\title{
PERIODONTAL STATUS IN PATIENTS WITH DISEASES OF HEPATOBILIARY SYSTEM, BURDENED WITH TOBACCO AND DRUG ADDICTION
}

DOI: 10.36740/WLek202003121

\author{
Anastasia I. Furdychko, Marta P. Ilchyshyn, Irena R. Fedun, Adriana Ya. Barylyak, Oksana M. Slaba, Lesya M. Khoroz \\ DANYLO HALYTSKY LVIV NATIONAL MEDICAL UNIVERSITY, LVIV, UKRAINE
}

\begin{abstract}
The aim: To study the effect of drug addiction and smoking on the status of periodontal tissues in patients with hepatobiliary pathology.

Materials and methods: 58 smokers, 63 drug addicts with hepatobiliary pathology were examined and 92 persons of comparison group (with inflammatory periodontal diseases affected by hepatobiliary pathology, without addiction). Examination of patients included determination of iodine number by Svrakov, S-L and Stallard hygiene indices, PMA index and index PBI.

Results: The results of examination of smokers are worse in patients with cirrhosis than in patients with chronic toxic hepatitis and non-alcoholic steatohepatitis and also the results of these two groups was significantly worse than that of the comparison group (iodine number by Svrakov - 1,4 times and 1,3 times higher, PMA index - 1,7 times and 1,4 times worse, in accordance). The results of the study showed that drug addicts patients are worse values in patients with cirrhosis than in patients with chronic toxic hepatitis and non-alcoholic steatohepatitis and also the results of these two groups was significantly worse than that of the comparison group (iodine number by Svrakov - 1,5 times and 1,4 times higher, PMA index - 1,7 times and 1,5 times worse, in accordance).

Conclusions: Presence of hepatobiliary pathology in smokers and drug addicts increases the risk of periodontal diseases.
\end{abstract}

KEY WORDS: inflammatory periodontal diseases, hepatobiliary pathology, tobacco smoking, drug addiction

Wiad Lek. 2020;73(3):517-520

\section{INTRODUCTION}

There is a clear trend to the increase in the number of patients with chronic liver disease, where the presence of numerous harmful habits (smoking, addictive and toxic substances) is a confounding factor [1, 2, 3, 4]. Hepatobiliary system is also adversely affected by numerous pathogenic factors of endogenous origin, leading to impaired detoxification function with subsequent development of endotoxicosis $[5,6,7,8,9]$.

The relationship between hepatobiliary system diseases and dental pathology is conditioned by impaired barrier and antimicrobial functions of the liver, resulting in translocation of opportunistic pathogenic bacteria into organs and tissues of oral cavity $[10,11]$. History, aggravated with drug addiction and harmful habits, namely smoking, usually exacerbates manifestations of the underlying disease, and its clinical course becomes longer. These factors create obstacles to the quality of dental care $[2,4]$.

\section{THE AIM}

To study the effect of drug addiction and smoking on the status of periodontal tissues in patients with hepatobiliary pathology.

\section{MATERIALS AND METHODS}

121 persons, including 58 smokers (suffering from chronic toxic hepatitis (22 persons), steatohepatitis (22 persons), nonalcoholic steatohepatitis (20 persons), liver cirrhosis (16 persons), and 63 drug addicts (suffering from chronic toxic hepatitis ( 21 persons), nonalcoholic steatoSurveys have shown that drug use causes the development of diseases of GBS and impedes the development of pathology of periodontal tissues. Also, smoking worsens the course of GBD and periodontal tissue disorders.hepatitis (22 persons), liver cirrhosis (20 persons) were examined. Patients of both sexes aged 20-45 years were included into groups under study in order to investigate peculiarities of the status of periodontal tissues.

Examination of patients included history taking, objective examination of oral cavity, determination of iodine number by Svrakov, S-L and Stallard hygiene indices, PMA index and bleeding index (PBI).

The comparison group included 92 persons with inflammatory periodontal diseases affected by hepatobiliary pathology, without tobacco and drug addiction.

Patients of all groups under study were informed, and measures were taken for patient's health safety, observance of rights, human dignity and moral and ethical standards 
Table I. Index evaluation of the status of periodontal tissues in tobacco-dependent patients against the background of hepatobiliary system pathology

\begin{tabular}{ccccc}
\hline Groups & $\begin{array}{c}\text { Comparison group } \\
\text { (patients with inflammatory } \\
\text { diseases of periodontium) } \\
\mathbf{n = 9 2}\end{array}$ & $\begin{array}{c}\text { Smokers with } \\
\text { chronic toxic } \\
\text { hepatitis } \\
\mathbf{n = 2 2}\end{array}$ & $\begin{array}{c}\text { Smokers with } \\
\text { nonalcoholic } \\
\text { steatohepatitis } \\
\mathbf{n}=\mathbf{2 0}\end{array}$ & $\begin{array}{c}\text { Smokers with } \\
\text { liver cirrhosis } \\
\mathbf{n = 1 6}\end{array}$ \\
\hline lodine number by Svrakov, score & $1,72 \pm 0,02$ & $2,15 \pm 0,08^{*}$ & $2,29 \pm 0,05^{*}$ & $2,48 \pm 0,03^{*}$ \\
\hline S-L, score & $1,21 \pm 0,02$ & $2,17 \pm 0,04^{*}$ & $2,20 \pm 0,03^{*}$ & $2,32 \pm 0,02^{*}$ \\
\hline Stallard, score & $1,25 \pm 0,01$ & $2,15 \pm 0,04^{*}$ & $2,18 \pm 0,03^{*}$ & $2,29 \pm 0,02^{*}$ \\
\hline PMA, \% & $40,77 \pm 0,60$ & $59,31 \pm 1,73^{*}$ & $61,32 \pm 0,78^{*}$ & $67,8 \pm 1,18^{*}$ \\
\hline PBI, score & $1,21 \pm 0,03$ & $1,72 \pm 0,08^{*}$ & $2,01 \pm 0,04^{*}$ & $2,23 \pm 0,03^{*}$ \\
\hline
\end{tabular}

Note:

* - probability index $(p<0,05)$ compared to comparison group;

$\#$ - probability index $(p<0,05)$ compared to group of smokers with liver cirrhosis.

Table II. Index evaluation of the status of periodontal tissues in drug-addicted patients against the background of hepatobiliary system pathology

\begin{tabular}{ccccc} 
Groups & $\begin{array}{c}\text { Comparison group } \\
\text { (patients with inflammatory } \\
\text { diseases of periodontium) } \\
\mathbf{n = 9 2}\end{array}$ & $\begin{array}{c}\text { Drug-addicted } \\
\text { patients } \\
\text { with chronic toxic } \\
\text { hepatitis } \\
\mathbf{n = 2 1}\end{array}$ & $\begin{array}{c}\text { Drug-addicted } \\
\text { patients } \\
\text { with nonalcoholic } \\
\text { steatohepatitis } \\
\mathbf{n = 2 2}\end{array}$ & $\begin{array}{c}\text { Drug-addicted } \\
\text { patients } \\
\text { with liver } \\
\text { cirrhosis } \\
\mathbf{n}=\mathbf{2 0}\end{array}$ \\
\hline lodine number by Svrakov, score & $1,72 \pm 0,02^{*}$ & $2,38 \pm 0,06^{*}$ & $2,45 \pm 0,05^{*}$ & $2,67 \pm 0,02^{*}$ \\
\hline Silness-Loe, score & $1,21 \pm 0,02^{*}$ & $2,16 \pm 0,06^{*}$ & $2,18 \pm 0,04^{*}$ & $2,35 \pm 0,02^{*}$ \\
\hline Stallard, score & $1,25 \pm 0,19^{*}$ & $2,21 \pm 0,04^{*}$ & $2,28 \pm 0,02^{*}$ & $2,41 \pm 0,03^{*}$ \\
\hline PMA, $\%$ & $40,77 \pm 0,60^{*}$ & $62,40 \pm 0,54^{*} \#$ & $62,80 \pm 0,89^{*} \#$ & $67,32 \pm 1,21^{*} \#$ \\
\hline PBI, score & $1,21 \pm 0,03^{*}$ & $2,68 \pm 0,12^{*} \#$ & $2,71 \pm 0,11^{*} \#$ & $3,08 \pm 0,03^{*} \#$ \\
\hline
\end{tabular}

Note:

* - probability index $(p<0,05)$ compared to comparison group;

\# - probability index $(p<0,05)$ compared to group of drug addicts with liver cirrhosis.

in accordance with the principles of the Declaration of Helsinki on Human Rights, the Council of Europe Convention on Human Rights and Biomedicine, and the relevant laws of Ukraine.

\section{RESULTS}

All study results, shown in Table 1 indicate that the worst hygiene and periodontal indices were found in tobacco-dependent patients with liver cirrhosis. The results of examination of smokers of all groups of patients with hepatobiliary pathology probably exceeded $(\mathrm{p}<0,05)$ the values obtained in the comparison group. (Table I)

As a result of the conducted study it was found out that the examined tobacco-dependent patients with hepatobiliary pathology demonstrated significantly worse values in comparison with patients without somatic pathology. The result of iodine number by Svrakov in tobacco-dependent patients with hepatobiliary pathology was significantly $(p<0,05)$ higher than in the comparison group (1,3 times higher in patients with chronic toxic hepatitis and nonalcoholic steatohepatitis, and 1,4 times higher in patients with liver cirrhosis). Value of Silness-Loe hygiene index in tobacco-dependent persons was significantly $(\mathrm{p}<0,05)$ worse than that of the comparison group, in particular, 1,8 times worse in patients with chronic toxichepatitis and nonalcoholic steatohepatitis, and 1,9 times worse in patients with liver cirrhosis. The values of Stallard index were also significantly higher in smokers with hepatobiliary pathology: 1,7 times higher in patients with chronic toxic hepatitis and nonalcoholic steatohepatitis, and 1,8 times higher in patients with liver cirrhosis $(\mathrm{p}<0,05)$.

A similar trend was found during the analysis of the results of PMA index in tobacco-dependent persons: values were significantly $(\mathrm{p}<0,05)$ worse than the data in the comparison group ( 1,4 times worse in patients with chronic toxic hepatitis, 1,5 times worse in patients with nonalcoholic steatohepatitis, and 1,7 times worse in patients with liver cirrhosis). Presence of pronounced inflammatory process in periodontal tissues of tobacco-dependent persons with hepatobiliary system pathology is also evidenced by the values of PBI index, which significantly $(\mathrm{p}<0,05)$ exceeded the values of the comparison group $(1,4$ times higher in patients with chronic toxic hepatitis, 1,7 times higher in patients with nonalcoholic steatohepatitis, and 1,8 times higher in patients with liver cirrhosis).

During examination of oral cavity of drug-addicted patients with hepatobiliary system pathology, unsatisfactory oral hygiene with massive supra- and sub-gingival deposits was observed. Gingivae were significantly hyperemic and swollen, bleeding with slight mechanical irritation. In some addicted patients, namely active users and those who were in the post-abstinence period, xerostomia was observed. 
Drug addicts who were in remission for more than 1 year, a decrease in dryness of oral mucosa was reported.

Table II presents the results of index evaluation of the status of periodontal tissues in drug-addicted patients against the background of hepatobiliary system pathology.

The results of the study showed that drug addicts with hepatobiliary pathology had significantly worse values of the investigated indices compared to patients without somatic pathology. In particular, the result of iodine number by Svrakov of the comparison group was significantly different from addicted patients with chronic toxic hepatitis and in patients with nonalcoholic steatohepatitis (by 1,4 times), and 1,5 times different from drug-addicted patients with liver cirrhosis. The value of simplified Silness-Loe hygiene index in drug-addicted patients was significantly worse than that of the comparison group, namely, 1,8 times worse in patients with chronic toxic hepatitis and in patients with nonalcoholic steatohepatitis, and 1,9 times worse in patients with liver cirrhosis. The values of Stallard index were also significantly higher in smokers with hepatobiliary pathology: by 1,8 times in patients with chronic toxic hepatitis and in patients with nonalcoholic steatohepatitis, and by 1,9 times in patients with liver cirrhosis $(\mathrm{p}<0,05)$.

The results of PMA index in drug-addicted patients show pronounced inflammatory processes in gingivae and are significantly worse than the values of the comparison group (1,5 times worse in patients with chronic toxic hepatitis and in patients with nonalcoholic steatohepatitis, and 1,7 times worse in patients with liver cirrhosis). Intensive development of inflammation in periodontal tissues of drug-addicted patients with hepatobiliary system diseases is also confirmed by the results of PBI index, which are significantly worse than those of the comparison group $(\mathrm{p}<0,05)$.

When comparing the results of index evaluation in addicted patients with hepatobiliary pathology, it was found that the values of patients with liver cirrhosis are significantly $(p<0,05)$ worse than the values of drug-addicted patients with chronic toxic hepatitis and patients with nonalcoholic steatohepatitis (there was no significant difference between the values of the latter).

Research have shown that smoking worsens the course of hepatobiliary pathology and periodontal tissue disease. Also, drug use causes the development of hepatobiliary pathology and the pathology of periodontal tissues

\section{CONCLUSIONS}

Study data suggest that periodontal lesions occur much less often in non-addicted patients with inflammatory diseases of periodontium and without concomitant somatic pathologies, and their clinical manifestations are less pronounced than in drug addicts.

Thus, the presence of hepatobiliary system pathology in tobacco- and drug-addicted persons increases the risk of periodontal diseases and contributes to the severity of their manifestations.
Findings suggest that significantly worse oral health status in smokers is caused by not only inadequate care of oral cavity, but to a great extent by the effect of nicotine and its components on the organs and tissues of oral cavity.

With the help of clinical index evaluation, we became certain that addicted patients with hepatobiliary pathology increase the probability of inflammation in the periodontium, and the severity of its course correlates with the degree of development of the underlying disease and the presence of harmful habits.

\section{REFERENCES}

1. Ilchyshyn M.P, Furdychko A.I, Barylyak A.Ya. Poshyrenist zakhvoryuvan parodontu sered tyutyunozalezhnykh osib. [Prevalence of periodontal disease among tobacco users]. Dentistry news. 2018; 4 (97): 86-88. (In Ukrainian).

2. Furdychko A.I, Ilchyshyn M.P, Barylyak A.Ya. Vplyv zakhvoryuvan hepatobiliarnoyi systemy ta shkidlyvoyi zvychky tyutyunopalinnya na vynyknennya zapal'nykh zakhvoryuvan parodonta. [Effect of diseases of the hepatobiliary system and the harmful habit of smoking on the occurrence of inflammatory diseases of the periodontium]. Novyny stomatolohiyi. 2018;2 (95):53-6. (In Ukrainian).

3. Zaborskis A, Volkyte A, Narbutaite J. Virtanen Smoking and attitudes towards its cessation among native and international dental students in Lithuania. BMC Oral Health. 2017;17(1):106.

4. Furdychko A.I, Fedun I.R, Dyba A.Ya. Parodontolohichnyy status narkozalezhnykh khvorykh iz hepatobiliarnoyu patolohiyeyu. [Periodontal status of drug addicted patients with hepatobiliary pathology]. Klinichna stomatolohiya. 2016;2:20-23. (In Ukrainian).

5. Aronow WS. Nonalcoholic fatty liver disease is associated with coronary artery disease and subclinical atherosclerosis. Future Cardiology. 2016; 12(4):393-396.

6. Gronkjaer L. Periodontal disease and liver cirrhosis: A systematic review. SAGE open Medicine. 2015; 3(10):1177-1185.

7. Dahiya P, Kamal R, Sharma V et al. Hepatitis" - Prevention and management in dental practice. J Educ Health Promot. 2015;4:33.

8. Alakhali MS, Al-Maweri SA, Al-Shamiri HM et al. The potential association between periodontitis and non-alcoholic fatty liver disease: a systematic review. Clin Oral Investig. 2018; 0ct 24. D0l: 10.1007/ s00784-018-2726-1.

9. Lonardo A, Ballestri S. Nonalcoholic fatty liver disease: A precursor of the metabolic syndrome. Dig Liver Dis. 2015;47(3):181-190.

10. Kashivska RS, Rozhko MM, Melnychuk GM. Zminy rivnya zahalnoho bilka u syrovattsi krovi ta rotoviy ridyni khvorykh pry likuvanni heneralizovanoho parodontytu, poyednanoho iz khronichnymy khvorobamy pechinky. [Changes in the level of total protein in the serum and oral fluid of patients in the treatment of generalized periodontitis combined with chronic liver disease] Ukrayinskyy stomatolohichnyy almanakh. 2015;5:14-17. (In Ukrainian).

11. Furdychko A.I, Hasiuk P.A, Ivanchyshyn V.V et al. Clinical-laboratory justification of dependence of periodontal inflammatory diseases on the condinion of hepatobiliary system. Svit medytsyny ta biolohiyi. 2018;1(63):87-89. (In Ukrainian).

The research was conducted at Danylo Halytsky Lviv National Medical University, Department of therapeutic dentistry. 


\section{ORCID and contributionship:}

Anastasia I. Furdychko - 0000-0002-8677-428X ${ }^{A, B, D, F}$ Marta P. Ilchyshyn - 0000-0001-8226-8913 ${ }^{\text {B,D,F }}$ Irena R. Fedun - 0000-0002-1671-6893 ${ }^{A, C, F}$ Adriana Ya. Barylyak - 0000-0001-7271-7252 ${ }^{B, E, F}$ Oksana M. Slaba - 0000-0003-4566-7178 B,E,F Lesya M. Khoroz - 0000-0001-7779-3588 B,E,F

\section{Conflict of interest:}

The Authors declare no conflict of interest.

\section{CORRESPONDING AUTHOR}

\section{Anastasia I. Furdychko}

Danylo Halytskyy Lviv National Medical University

Peremyska St. 3a/1, Lviv, Ukraine

tel: +380676880214

e-mail:anfurd111@gmail.com

Received: 17.01 .2020

Accepted: 05.03 .2020

A - Work concept and design, B - Data collection and analysis, C - Responsibility for statistical analysis,

$\mathbf{D}$-Writing the article, $\mathbf{E}$-Critical review, $\mathbf{F}$ - Final approval of the article 